\title{
Evaluation of Red Cabbage Anthocyanins after Partial Purification on Clay
}

\author{
Toni Jefferson Lopes, Sandra Regina Yaginuma, Mara Gabriela Novy Quadri* and \\ Marintho Bastos Quadri \\ Departamento de Engenharia Química e Engenharia de Alimentos; Universidade Federal de Santa Catarina; C. P.: \\ 476; 88040-900; Florianópolis - SC - Brasil
}

\begin{abstract}
The aim of this work was to evaluate the red cabbage anthocyanins quality after purification by static adsorption assays on clay (Tonsil Terrana 580FF). Thin-layer chromatography analysis and scan spectrometry on UV-Visible showed a good dye stability of the pigment interacting with the clay. The use of pH 3.0 buffer during the batch assays provided a protective effect on the cabbage anthocyanins, limiting the dye acid hydrolyses. Analyses of the reducing sugars contents of the extract showed that clay retained $20 \%$ average of total free sugars under the test conditions.
\end{abstract}

Key words: Thin-layer chromatography, spectrophotometry, purification, batch conditions

\section{INTRODUCTION}

Flavonoids comprise a group of phenolic pigments that are mainly responsible for several colors found in the flowers, fruits and leaves (Curtright et al., 1996; Bobbio and Bobbio, 1995). Anthocyanins, a flavonoid subgroup, show many benefits to human health, such as the cardio protector effect, that is related to the ability to inhibit the lipids peroxidation and to cushion other processes that involve related oxygen species (Renaud and De Lorgeril, 1992; Cook and Samman, 1996; Noda et al., 2000; Heim et al., 2002). Anthocyanins are soluble in water and ethyl alcohol (Peterson and Dwyer, 2000, Curtright et al., 1996), and as glycosidic pigments, derived from the 2-fenilbenzopirilium or flavilium nucleus, are distinguished by the B ring structure as shown in Figure 1 (Jackman and Smith, 1992).
They naturally occur in the heteroglycosidic form, containing one or more molecules of sugar. In the aglycon form, it is also known as anthocyanidin. The most common sugars linked to anthocyanins molecules are glucose, rhamnose, xylose, galactose, arabinose and fructose (Francis, 1989). These sugars can be monoglycosides, diglycosides and triglycosides replaced directly at aglycon. The anthocyanins color depends on its structure, number and position of hydroxyl and methoxyl groups present in its composition, and the structural forms. Quinoidal base, Flavilium cation, Chalcone and Pseudobase are a function of the solution $\mathrm{pH}$ as shown in Figure 2 (Jackman and Smith, 1992; Cooper-Driver, 2001).

Red cabbage, a rich source of anthocyanins, produces a very concentrated juice which easily deteriorates due to the high free reducing sugar contents fermentation. Red cabbage (Brassica

\footnotetext{
*Author for correspondence: mara@enq.ufsc.br
} 
oleracea) anthocyanins were identified as cyanidin-3,5-diglucoside and cyanidin-3sophoroside-5-glucoside, the latter found in various acylated form (Dirby et al., 2001; Jackman and Smith, 1992; Hrazdina et al., 1977).

Adsorption is a separation process that can be used to make partial or total purification of anthocyanins (Lopes et al., 2007). Traditional adsorbents such as resins as Amberlite XAD-7 (Coutinho et al., 2004) results in an expensive product. Recent works have shown the viability of using clay Tonsil Terrana 580FF as alternative adsorbent material to decrease costs. On the other hand, possible anthocyanins modifications during the purification process is not yet known (Lopes et al., 2005). This work aims to evaluate the effect of this adsorbent on possible structural modifications on red cabbage anthocyanins after adsorptiondesorption process clay.

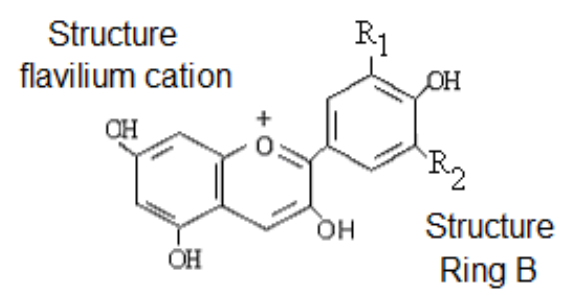

\begin{tabular}{|c|c|c|c|}
\hline Cyanidin & $\begin{array}{l}\mathrm{R}_{1}=\mathrm{OH} \\
\mathrm{R}_{2}=\mathrm{H}\end{array}$ & Malvidin & $\begin{array}{l}\mathrm{R}_{1}=\mathrm{OCH}_{3} \\
\mathrm{R}_{2}=\mathrm{OCH}_{3}\end{array}$ \\
\hline Pelargonidin & $\begin{array}{l}\mathrm{R}_{1}=\mathrm{H} \\
\mathrm{R}_{2}=\mathrm{H}\end{array}$ & Peonidin & $\begin{array}{l}\mathrm{R}_{1}=\mathrm{OCH}_{3} \\
\mathrm{R}_{2}=\mathrm{H}\end{array}$ \\
\hline Delphinidin & $\begin{array}{l}\mathrm{R}_{1}=\mathrm{OH} \\
\mathrm{R}_{2}=\mathrm{OH}\end{array}$ & Petunidin & $\begin{array}{l}\mathrm{R}_{1}=\mathrm{OCH}_{3} \\
\mathrm{R}_{2}=\mathrm{OH}\end{array}$ \\
\hline
\end{tabular}

Figure 1 - Molecular structure of anthocyanins.<smiles>O=c1ccc2cc(O)c(-c3ccc(O)cc3)oc-2c1</smiles>

A: Quinoidal base (blue)<smiles>[R]C1=CC(C(=O)C(O)C=C2C(O)=CC(=O)CC2O)C=C(O)C1</smiles>

C: Chalcone (colorless)<smiles></smiles>

$\mathrm{AH}+$ : Flavilium cation (red)<smiles>[R]c1cc(C2(O)Oc3cc(O)cc(O)c3C=C2Cl)cc([R])c1O</smiles>

B: Pseudobase or carbinol (colorless)

Figure 2 - Structural Transformation of anthocyanins according to pH (Jackman and Smith, 1992).

\section{MATERIAL AND METHODS}

\section{Material}

Tonsil Terrana Clay 580 FF (Protocol: 1043-84), supplied by Süd Chemie of Brazil Ltda was used as adsorption material for the partial purification of red cabbage juice anthocyanin. Tonsil Terrana $580 \mathrm{FF}$ is natural smectitic clay, with chemical composition shown in Table 1. Its particle size distribution is shown in Table 2, obtained by laser diffraction (CILAS, model 1064L).

The texture of Tonsil Terrana clay was characterized using the Autosorb-1 (Quantachrome) equipment (Table 3), according to BET, DR (Dubinin-Radushkevich) and HK (Horvath-Kawazoe) methods. 
Natural red cabbage pigment (liquid) and commercial dye (Chr. Hansen Ltda), as a water soluble powder, were used in this work. The red natural dye was obtained by squeezing the cabbage, followed by vacuum filtration and centrifugation at $3500 \mathrm{rpm}$ for 20 minutes and $25^{\circ} \mathrm{C}$. Reducing sugar quantification was done according to MILLER (1959).

Table 1 - Chemical composition of Tonsil Terrana Clay 580 FF.

\begin{tabular}{lc}
\hline Contents & \% in mass \\
\hline Silicon Oxide $\left(\mathrm{SiO}_{2}\right)$ & 55.50 \\
Aluminum Oxide $\left(\mathrm{Al}_{2} \mathrm{O}_{3}\right)$ & 16.36 \\
Iron Oxide $\left(\mathrm{Fe}_{2} \mathrm{O}_{3}\right)$ & 7.53 \\
Calcium Oxide $(\mathrm{CaO})$ & 2.45 \\
Sodium Oxide $\left(\mathrm{Na}_{2} \mathrm{O}\right)$ & 0.11 \\
Potassium Oxide $\left(\mathrm{K}_{2} \mathrm{O}\right)$ & 2.94 \\
Manganese Oxide $(\mathrm{MnO})$ & 0.18 \\
Titanium Oxide $\left(\mathrm{TiO}_{2}\right)$ & 0.90 \\
Magnesium Oxide $(\mathrm{MgO})$ & 2.28 \\
Phosphorus Oxide $\left(\mathrm{P}_{2} \mathrm{O}_{5}\right)$ & 0.35 \\
Fire Loss $\left(\mathrm{T}=950^{\circ} \mathrm{C}\right)$ & 10.64 \\
\hline
\end{tabular}

Table 2 - Particle diameter (Dp) distribution of Tonsil Terrana Clay 580 FF.

\begin{tabular}{cc}
\hline Particle diameter $(\mu \mathrm{m})$ & \% Cumulative Particles \\
\hline$\geq 53.00$ & 96.0 \\
$53.00>\mathrm{D}_{\mathrm{p}} \geq 16.33$ & 90.0 \\
$16.33>\mathrm{D}_{\mathrm{p}} \geq 5.87$ & 50.0 \\
$5.87>\mathrm{D}_{\mathrm{p}}>0.00$ & 0.0 \\
\hline
\end{tabular}

Table 3 - Physical properties of Tonsil Terrana Clay 580 FF.

\begin{tabular}{lc}
\hline Property & Clay “in natura" \\
\hline Superficial area BET $\left(\mathrm{m}^{2} \mathrm{~g}^{-1}\right)$ & 112.3 \\
Micropore area DR method $\left(\mathrm{m}^{2} \mathrm{~g}^{-1}\right)$ & 123.7 \\
Micropore volume DR method $\left(\mathrm{cm}^{3} \mathrm{~g}^{-1}\right)$ & 0.04395 \\
Pore width HK method (A) & 4.975 \\
\hline
\end{tabular}

\section{Batch Assays}

Triplicate batch assays were made at $25^{\circ} \mathrm{C}$. To $50 \mathrm{~mL}$ red cabbage dye solution with known initial concentration, $0.5 \mathrm{~g}$ clay was added to the isotherms. Aliquots were taken from the supernatant during the batch adsorption process. The $\mathrm{pH}$ was corrected to 3.0 considering the spectrometry scan sensibility at the wavelength of $550 \mathrm{~nm}$ (Sondheimer and Kertesz, 1948).

\section{Spectrophotometry and Thin-Layer Cromatography}

Thin-layer chromatography and scan spectrometry on UV-Visible were used to detect the possible changes occurring in the red cabbage anthocyanins during the adsorption and desorption process on clay. Pigments from: a) squeezed red cabbage extract, and b) commercial powder in aqueous solution were analyzed before, during and after the adsorption-desorption process according to Curtright et al. (1996). The samples of red cabbage dye solution were treated by thin layer chromatography to detect the possible changes due to the clay-dye interaction. The solvent used was $\mathrm{HCl} /$ formic acid/water at 19.0/39.6/41.4 (v/v) proportion (Francis, 1982). Sugars bound to the anthocyanins molecules were removed by the hydrolysis (Curtright et al., 1996).

Aglycone is a less polar compound and migrates more slowly in the ascending thin-layer chromatography plate than a mono or diglycoside.

\section{RESULTS AND DISCUSSION}

\section{Batch Assays}


Table 4 gives of the Freundlich equation (Equation 1) parameters fitted on the experimental results. It was observed that for lower $\mathrm{pH}$ values, $\mathrm{k}$ was high, showing a greater adsorption capacity. Lower values of $\mathrm{n} \quad(\mathrm{n}<1), \quad$ as for $\mathrm{pH} 3.0$, indicated a solute tendency to migrate to the solid, which means that $\mathrm{pH} 3.0$ was the better condition for separation. Figures 3 and 4 show the results of the Freundlich isotherm fitted to the adsorption data of red cabbage commercial dye on Tonsil Terrana clay $580 \mathrm{FF}$, at pH 3.0 and 5.0.

$q_{e}=\mathrm{kC}_{\mathrm{e}}^{\mathrm{n}}$

Table 4 - Experimental conditions and Freundlich parameters fitted to experimental adsorption results of red cabbage commercial dye.

\begin{tabular}{ccc}
\hline Experimental conditions & Commercial Dye $\mathbf{p H}=\mathbf{3 . 0}$ & Commercial Dye pH= 5.0 \\
\hline $\mathrm{R}(\mathrm{cm})$ & 0.0007 & 0.0007 \\
$\varepsilon_{\mathrm{p}}$ & 0.53 & 0.53 \\
$\rho_{\mathrm{d}}\left(\mathrm{g} \mathrm{cm}^{-3}\right)^{*}$ & 1.74 & 1.74 \\
$\mathrm{C}_{0}\left(\mathrm{mg} \mathrm{cm}^{-3}\right)$ & 1.1 & 1.1 \\
$\mathrm{~V}\left(\mathrm{~cm}^{3}\right)$ & 50 & 50 \\
$\mathrm{~m}_{\mathrm{ad}}(\mathrm{g})$ & 0.5 & 0.5 \\
\hline \multicolumn{3}{c}{} \\
\hline $\mathrm{k}$ & Adjusted Parameters of Freundlich Isotherm \\
$\mathrm{n}$ & $\mathrm{pH} \mathrm{3}$ & $\mathrm{pH} \mathrm{5}$ \\
\hline Variance & 308.607 & 195.73 \\
Correlation & 0.8988 & 1.00 \\
& 3.35 & - \\
& 0.9939 & 0.9221 \\
\hline
\end{tabular}

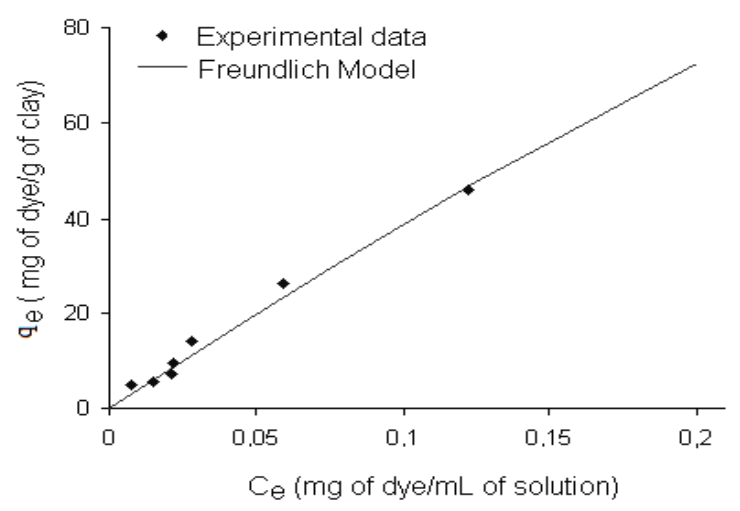

Figure 3 - Adsorption isotherm of red cabbage commercial dye on clay, $\mathrm{pH} 3$.

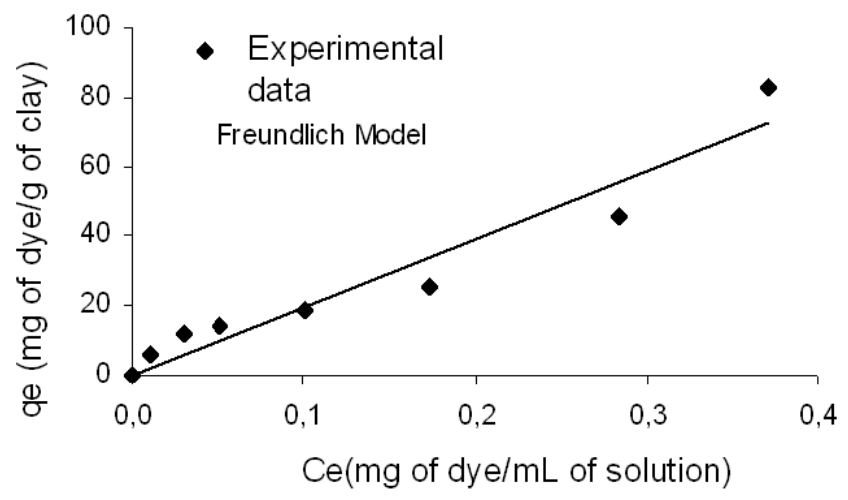

Figure 4 - Adsorption isotherm of red cabbage commercial dye on clay, pH 5. 
Figure 5 shows the experimental data and the Freundlich model fitted to the adsorption isotherm of natural dye on Tonsil Terrana clay $580 \mathrm{FF}, \mathrm{pH}$ 3.0. It was observed that the adsorption isotherm was unfavorable, with a tendency of the solute to remain in the liquid phase. Adjusted values of Freundlich isotherm were 36.04 and 1.93 for $\mathrm{k}$ and $\mathrm{n}$, respectively, $\mathrm{R}=0.9658$.

The different $\mathrm{k}$ values found for red cabbage commercial and natural dyes showed different solutions constitutions: the former was less competitive solute than the latter (Coutinho et al., 2004).

To evaluate the clay selectivity for separation of anthocyanins in red cabbage juice, adsorbed sugar contents were quantified in eight assays using different Tonsil Terrana clay 580 FF mass quantity. Results are shown in Figure 6.

It was observed that the Tonsil Terrana clay 580 FF adsorbed a relatively small sugar amount, about $16 \%$, initially present in the red cabbage juice (sugar initial concentration of $40.18 \mathrm{mg} \mathrm{mL}^{-}$ $\left.{ }^{1}\right)$. Even when the clay mass was raised about $1300 \%$, there was no significant variation in the adsorbed sugars content. This result showed a good selectivity of the clay regarding to the dye preferential adsorption of the sugar.

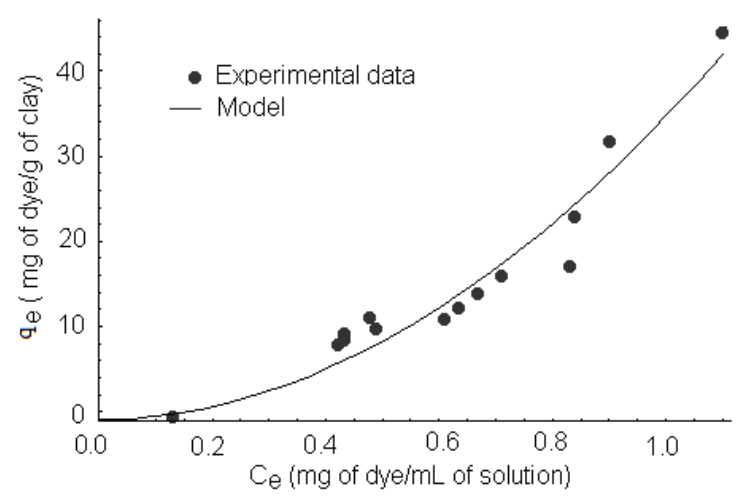

Figure 5 - Adsorption isotherm of red cabbage natural juice on clay, pH 3.

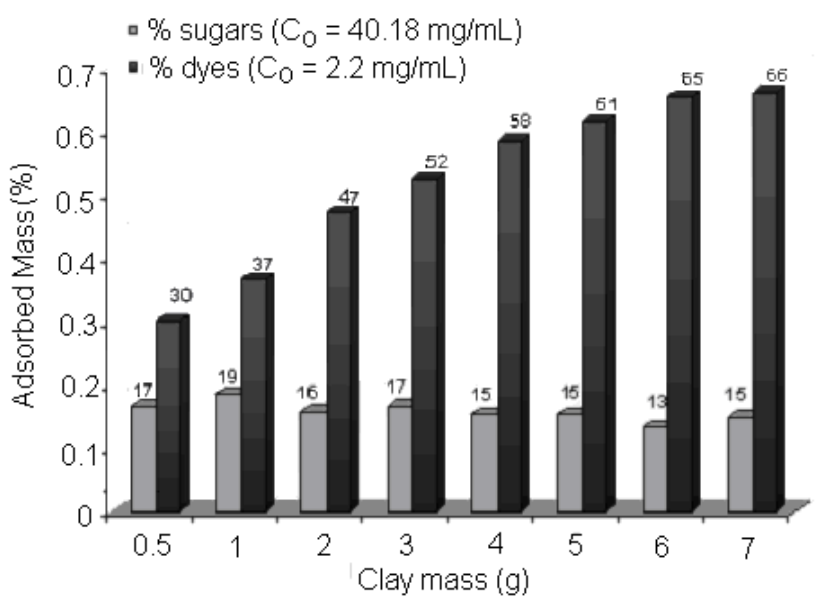

Figure 6 - Percentage of sugar and anthocyanins of red cabbage adsorbed on Tonsil Terrana clay $580 \mathrm{FF}$. 
Spectrophotometry Chromatography

Spectrometry scans of commercial and natural red cabbage anthocyanins, before, during and after the adsorption-desorption process are shown in Figures 7 and 8 . A characteristic absorbance peak at the ultraviolet band, between $310-335 \mathrm{~nm}$, indicates the presence of acylated organic acids at the anthocyanin molecule (Harborne, 1967). Another peak was observed at the visible band, around $540 \mathrm{~nm}$, for the aglycone.

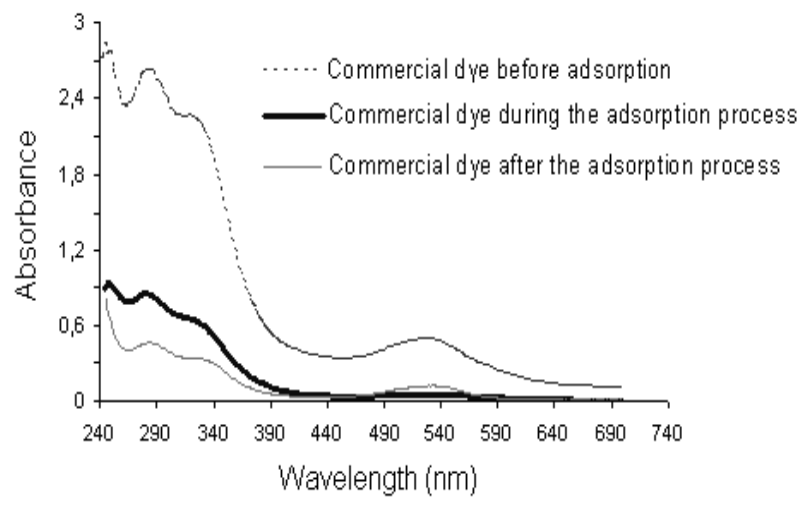

Figure 7 - Scan spectrometry on UV-Visible to red cabbage commercial dye.

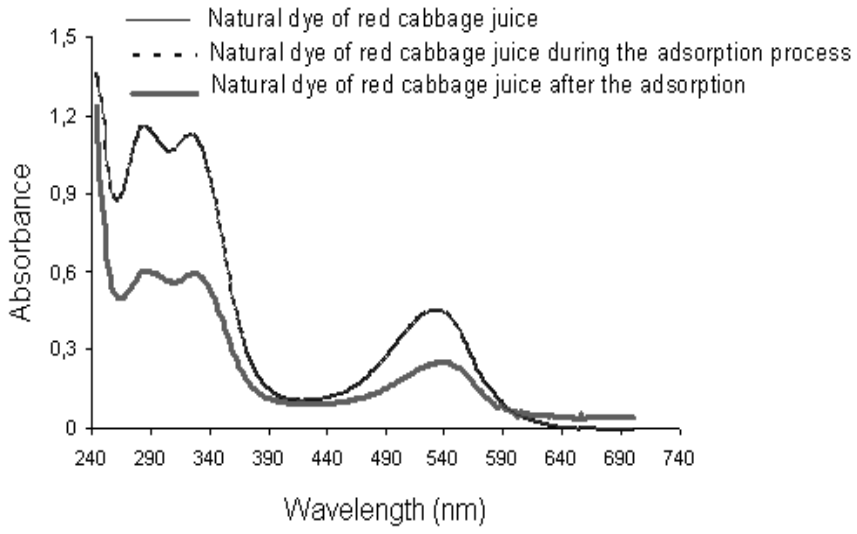

Figure 8 - Scan spectrometry on UV-Visible to red cabbage natural dye.

Jacobsi and Schoonheydt (1999) and Czímerová et al. (2004) studied variations promoted in the spectrum by changing the molecular structures of the dyes, which is detected by the batochromic occurrence. The increase of the absorption wavelength of anthocyanins was attributed to the number of auxochromic hydroxyl group increase, due to the buffer addition into the material or for the clay's ability of changing cations.

Paper chromatography was performed for the following samples: 1.commercial dye before the adsorption; 2.commercial dye after the adsorption process; 3. commercial dye after the desorption process; 4.natural dye of red cabbage juice; 5 . natural dye of red cabbage juice after the adsorption process; 6 . natural dye of red cabbage juice after the desorption. Fig. $9 \mathrm{a}$ is a chromatogram found by Curtright et al. (1996), a reference for this study. Figure $9 b$ (black and white representation and colored photograph) is the chromatogram obtained for the samples 1 to 6 cited above. The Rf of each component, that is the characteristic distance run in the chromatography paper, are shown in the Table 5. D and S are the space covered by the sample and solvent, respectively. 


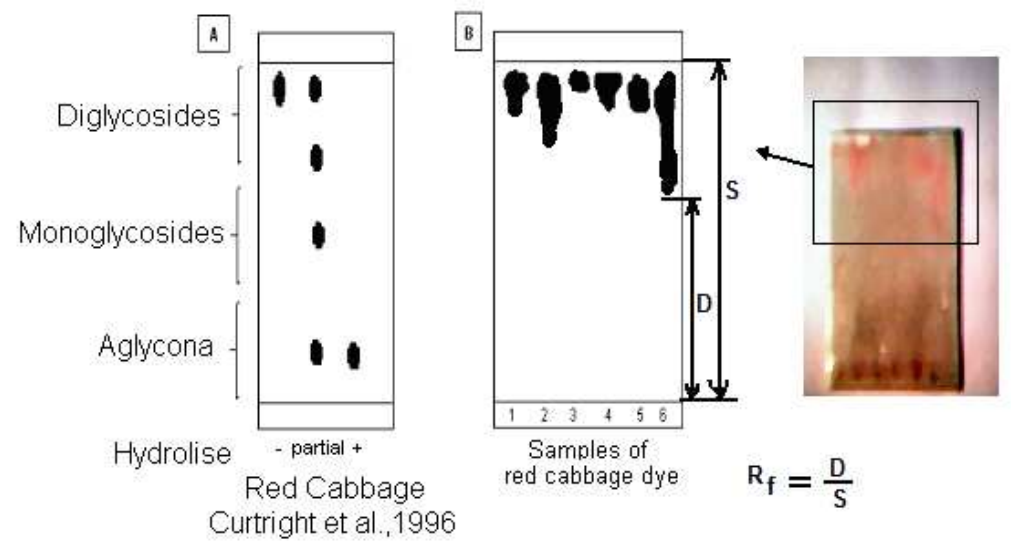

Figure 9 - Samples chromatogram during the batch process.

Table 5 - Paper chromatography Rf parameter for the anthocyanins samples.

\begin{tabular}{lc}
\hline Sample & Rf \\
\hline 1.commercial dye before adsorption & 0.84 \\
2.commercial dye during the adsorption process & 0.75 \\
3. commercial dye after the desorption process & 0.92 \\
4. natural dye of red cabbage juice & 0.85 \\
5. natural dye of red cabbage juice during the adsorption process & 0.85 \\
6. natural dye of red cabbage juice after the desorption & 0.62 \\
\hline
\end{tabular}

According to Curtright et al. (1996), the first $\mathrm{R}_{\mathrm{f}}$, superior to 0.62 , refers to anthocyanin without hydrolysis, the second shows partial dye hydrolysis ( $\mathrm{R}_{\mathrm{f}}$ from 0.0 to 1.0 ) and finally the third is a characteristic spot of a complete hydrolyzed molecule $\left(\mathrm{R}_{\mathrm{f}}\right.$ inferior to 0.32$)$. The Rf values found in this work were greater than 0.62 , indicating that red cabbage anthocyanins were not dissociated in mono or diglycosides, or even aglycones in the process on clay, and clay was a good material to partially purify the anthocyanins from the red cabbage.

The results indicated that the use of the buffer solution to lower the $\mathrm{pH}$ for the partial purification of the anthocyanin improved the cyanidins stability avoiding the hydrolyzes.

\section{CONCLUSIONS}

Thin-layer chromatography and scan UV/Visible spectrometry analysis did not reveal did not reveal structural changes in the anthocyanins molecules which showed the dye stability during the separation process. Scan spectrophotometry analyzes indicated that due to the fact that the system reached almost instantly the dye concentration balance between the supernatant and the adsorbent, the formation of aggregates among the clay and the red cabbage anthocyanins was avoided, preserving the dye molecules characteristics. Thinlayer chromatography analysis permits to conclude that the use of buffer solution during the adsorption process to adjust the $\mathrm{pH}$, avoided the dye hydrolisis, phenomenon occurred when $\mathrm{HCl}$ solution is used

\section{ABBREVIATIONS}

$\mathrm{D}_{\mathrm{p}} \quad$ Particle diameter

$(\mu \mathrm{m})$

$\mathrm{k} \quad$ Freundlich adsorption isotherm constant

$\mathrm{n} \quad$ Freundlich isotherm exponent

$\mathrm{q}_{\mathrm{e}} \quad$ Dye concentration in solid fase

$\mathrm{C}_{\mathrm{e}} \quad$ Dye concentration in liquid fase

$\mathrm{C}_{0} \quad$ Initial dye concentration in liquid fase

$\mathrm{m}_{\mathrm{ad}} \quad$ Adsorbent mass

R Particle ray

V Dye solution volume

$\left(\mathrm{g} \mathrm{g}^{-1}\right)$

$\left(\mathrm{g} \mathrm{cm}^{-3}\right)$

$\left(\mathrm{g} \mathrm{cm}^{-3}\right)$

$(\mathrm{cm})$

$\left(\mathrm{cm}^{3}\right)$

$R_{f} \quad$ Proportion between the distance that the dye went through and the distance that the solvent went through the thin-layer chromatography $\left(\mathrm{cm} \mathrm{cm}^{-1}\right)$

D Distance that the dye went through $(\mathrm{cm})$

$\mathrm{S} \quad$ Distance that the solvent went through $\quad(\mathrm{cm})$

$\rho_{\mathrm{d}} \quad$ Particle specific mass $\quad\left(\mathrm{g} \mathrm{cm}^{-3}\right)$

$\varepsilon_{\mathrm{p}} \quad$ Particle porosity.

DR Dubinin-Radushkevich method

HK Horvath-Kawazoe method 


\section{REFERENCES}

Bobbio, P. A.; Bobbio, F.O. (1995) Química do processamento de alimentos: pigmentos, 2 ed.,Campinas, Varela, pp 105-120

Cook, N. C; Samman, S (1996) Flavonoids chemistry, metabolism, cardioprotective effects, and dietary sources Nutritional. Biochemistry. 7, 66-76.

Cooper-Driver, G.A. (2001) Contributions of Jeffrey Harbone and co-workers to the study of anthocyanins, Phytochemistry, 56, 229-236.

Coutinho, M.R.; Quadri, M.B.; Moreira, R.F.P.M.; Quadri, M.G.N. (2004) Partial purification of anthocyanins from Brassica oleracea (Red Cabbage). Separ. Sci. Technol., 39(16), 3769-3782.

Curtright, R.; Rynearson, J.A.; Markwell, J. (1996) Model Compounds for Learning about more than pH. J. Chem. Educ., 73(4), 306-309.

Czímerová, A.; Jankovic, L.; Bujdák, J. (2004) Effect of the exchangeable cations on the spectral properties of methylene blue in clay dispersions. $J$. Colloid Interf. Sci., 274, 126-132.

Dirby, M.; Westergaard, N.; Stapelfeldt, H. (2001) Light and heat sensitivity of red cabbage extract in soft drink model systems. Food Chem., 72, 431437.

Francis, F.J. (1982) In Anthocyanins as Food Colors; Markakis, P., Ed. Academic Express, New York, pp. 187-207.

Francis, F.J. (1989) Food colorants: Anthocyanins. Crit. rev. food sci., 28, 273-314.

Harborne, J.B. (1967) Comparative Biochemistry of the Flavonoids. Academic Press, London.

Hrazdina, G.; Iredale, H.; Mattick, L.R. (1977) Anthocyanin composition of Brassica oleracea cv. Red Danish. Phytochemistry, 16(2), 297-299.
Heim, K.E., Tagliaferro, A. R., Bobilya, D. J. (2002) Flavonoid antioxidants: chemistry, metabolism and structure-activity relationships. J. Nutr. Biochem., 13, 572-584.

Jackman, R.L. Smith, J.L. (1992) Anthocyanins and betalains. In: Hendry, G.A.F. and Houghton, J.D. Natural Food Colorants. London: Blackie Academic, pp. 183-241

Jacobsi, K.Y.; Schoonheydt, R.A. (1999) Spectroscopy of Methylene Blue-Smectite Suspensions. J. Colloid Interf. Sci., 220, 103-111.

Lopes, T. J., Goncalves, O. H., Barros, R. B., Capelli, F.C.R.; Machado, R.A.F.; Quadri, M.G.N.; Quadri, M.B. (2005) Adsorption of natural dyes on clay fixed on polymers. Braz. Arch. biol. techn., 48, 275-280.

Lopes, T.J., Quadri, M.G.N., Quadri, M. B. (2007) Recovery of anthocyanins from red cabbage using sandy porous medium enriched with clay. Appl. Clay Sci., 37, 97-106.

Miller, G. L. (1959) Use of dinitrosalicylic acid reagent for determination of reducing sugar. Anal. Chem. 31(3), 426-428.

Noda,Y.;Kneyuki,T.; Igarashi, K.; Mori, A.; Packer, L. (2000) Antioxidant activity of nasunin, an anthocyanin in eggplant peels, Toxicology, 148, 119-123.

Peterson, J.; Dwyer, J. (2000) An Informatics Approach to Flavonoid Database Development, J. Food Compos. Anal., 13, 441-454.

Renaud, S.; De Lorgeril, M. (1992) Wine, alcohol, platelets, and the French paradox for coronary heart disease. Lancet, 339(8808), 1523-1526.

Sondheimer, E.; Kertesz, Z. I. (1948) The Anthocyanin of Strawberries. J. Am. Chem. Soc., 70, 3476.

Received: July 23, 2010; Revised: April 27, 2011; Accepted: July 20, 2011. 